\title{
A comparative analysis of clientelism in Greece, Spain, and Turkey: the rural-urban divide
}

\section{Kursat Cinar}

To cite this article: Kursat Cinar (2016) A comparative analysis of clientelism in Greece, Spain, and Turkey: the rural-urban divide, Contemporary Politics, 22:1, 77-94, DOI: 10.1080/13569775.2015.1112952

To link to this article: https://doi.org/10.1080/13569775.2015.1112952

册Published online: 13 Jan 2016.

Submit your article to this journal $\pi$

Џll Article views: 408

Q View related articles $₫$

View Crossmark data $[\pi$

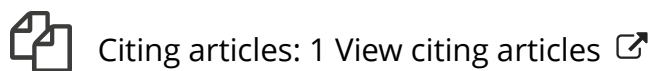




\title{
A comparative analysis of clientelism in Greece, Spain, and Turkey: the rural-urban divide
}

\author{
Kursat Cinar \\ Department of Political Science, Bilkent University, Ankara, Turkey
}

\begin{abstract}
This article examines the evolution of patron-client relationships in Greece, Spain, and Turkey through the prism of the rural-urban divide. It traces which modes of clientelism (rural or urban) are more evident in these countries today, and why. Further, it finds that in rural modes of clientelism, normative bonds of deference and loyalty with a Weberian notion of 'traditional authority' and affective ties between political patrons and clients are more observable whereas urban modes of clientelism usually yield Downsian competition between political machines with more coercive motives. It suggests that these two notions of clientelism are not mutually exclusive but should rather be seen in a continuum. More generally, this article demonstrates the need in the existing literature for more contextualized analyses that take into account differences between socioeconomic and geographical antecedents of rural vs. urban clientelism and their divergent political reflections.
\end{abstract}

\section{KEYWORDS}

Clientelism; Greece; Spain; Turkey; machine politics; rural clientelism

\section{Introduction}

Main puzzles in the clientelism literature today revolve around three major questions: How does clientelism work?; What causes or prevents shifts away from clientelism?; Is clientelism, along with other kinds of distributive politics, consistent with the norms of democracy, and why? (Kitschelt \& Wilkinson, 2007; Stokes, Dunning, Nazareno, \& Busco, 2013). This paper attempts to address the first two questions (it does not deal with the normative aspect of clientelism), by theoretically analysing different modes of clientelism (urban vs. rural), in light of three comparative cases, Greece, Spain, and Turkey. Taking into account these theoretical and empirical investigations, the article deals with the reflections of clientelism in contemporary politics. It argues that rural vs. urban modes of patron-client relationships differ sufficiently enough for a theoretical investigation. Further, an empirical discussion of this rural-urban divide in clientelism, in light of the Greek, Spanish, and Turkish cases consolidates the conviction that this theoretical distinction has real-life implications.

The structure of this paper is as follows. In the following section, a brief overview of the clientelism literature is first provided. Then, specific attention is paid to the rural-urban divide in patron-client relationships. The article highlights the need in the existing 
literature for more contextualized analyses that take into account differences between socioeconomic and geographical antecedents of rural vs. urban clientelism and their divergent political reflections. Section 3 sets forth the discussion of different modes of patronage networks in three Southern European countries, that is, Greece, Spain, and Turkey. In-depth historical analyses of political and socioeconomic changes are provided so as to understand the evolution of clientelism in these countries. Last section discusses the current state of patronage systems in these countries and underlines which modes of clientelism (rural or urban) are more evident in these countries today and why.

\section{Rural-urban divide in clientelism}

Before delving into the specifics of this paper, it would be appropriate to start with what we understand by 'patron-client relationships' and why we should be interested in these relationships. Older notions of clientelism underline dyadic and reciprocal nature of sociopolitical relationships between individuals of higher socioeconomic status (patron) and persons of lower status (client) (see for instance, Kaufman, 1974; Lande, 1973; Lémarchand \& Legg, 1972; Powell, 1970; Scott, 1972; Theobald, 1983). I conceptualize clientelism as selective, particularistic, and hierarchical mutual support systems (be it at the dyadic or community level) through a multitude of favours to electors in exchange for political support (usually votes) (cf. Alamdari, 2005; Ansell \& Mitchell, 2011; Auyero, 1999; Burgwal, 1995; Chaves, 2002; Corstange, in press; Garcia-Guadilla, 2002; Keating, 1999; Lauth, 2000; Levitsky \& Way, 2012; Lindberg \& Morrison, 2008).

Comprehending patron-client relationships is illuminating for domestic power politics in a country (see Anderson, 1967, pp. 89-93; Scott, 1967, p. 127). Even the most centralized governments have utilized the intertwined web of patron-client relationships and delegated power to notables in the periphery so as to continue and if possible strengthen their political clout at the centre. Clientelism, in this regard, enables politicians to minimize electoral risk via targeting their core constituencies and true partisans whose electoral support is certain (Diaz-Cayeros, Magaloni, \& Weingast, 2002, p. 202). Patron-client relationships are also enlightening for some of the cases, which could otherwise have been seen 'irrational'. The compliance of low-status actors to higher authority and the reluctance of these actors to form horizontal alliances with their peers can only be grasped through the prism of patron-client relationships (Kaufman, 1974; Powell, 1970).

Clientelism is extant both in developed and developing countries (Magaloni, Diaz-Cayeros, \& Estevez, 2007, p. 182). Contrary to earlier works on clientelism (such as Lemarchand \& Legg, 1972; Scott, 1972), patron-client relationships do not simply wither away with enhancements in socioeconomic development and political institutions. They usually evolve into new forms, as seen in the cases under analysis in this research.

A division between rural and urban modes of clientelism can be helpful to grasp this sociopolitical phenomenon even better. According to Kitschelt (2000), these two types of clientelism stand on the two ends of the spectrum. On one hand, we observe normative bonds of deference and loyalty in rural clientelism. On the other, there is competition between providers of selective and particularistic incentives in urban clientelistic settings. Rural-traditional clientelism calls for the Weberian 'traditional authority', where 'the person exercising power is not a superior, but a personal chief' (Weber, 1957). This type of clientelism is observed mostly in underdeveloped regions of many states, where affluence, 
literacy, and modes of communication are not well-developed. In this regard, rural 'patron' acts as a bridge between commoners and the outside world (e.g. Lerner, 1958). In rural areas, we observe affective ties between patrons and their clients. Intrinsic reciprocity (rather than instrumental reciprocity) is central in rural patronage systems (cf. Finan \& Schechter, 2012). ${ }^{1}$ Clientelistic ties in rural areas are usually buttressed by ritual gift exchanges, which create a feeling of obligation among recipients (and lower defection). The 'moral' part of the story about rural patron-client relationships is emphasized heavily by local patrons so as to achieve the highest levels of adherence and commitment by the rural population. In an interesting study, Hicken (2007) finds out that a Buddhist monk in rural Thailand declared that it was immoral to take money from one candidate and vote for another.

On the other hand, urban forms of patron-client relationships revolve around a more Downsian framework, where political parties and party leaders are motivated by the desire for power, income, and prestige that accrue to those who gain and hold political office (Wilson, 1961). Political machines are central to urban clientelism. Machine politics is dedicated to mobilizing votes or demobilizing opposition for the purpose of winning elections and the spoils of office. Material inducements such as jobs are exchanged for the votes of low-skilled citizens, lucrative contracts for project are exchanged for financial support from the entrepreneurial class, and favours in administration of law are exchanged for votes (Keiser, 2001).

The need of vast institutional networks for political machines are exemplified in many cases, such as the koenkai (affiliate local organization) system in Japanese politics or high levels of success for the Peronist Party in areas with dense party organizations (Auyero, 1999; Grzymala-Busse, 2008; Stokes, 2005). The span of urban clientelism can affect even ideologically based parties like the leftist parties in Latin America (Coppedge, 2001; Grzymala-Busse, 2008). Ethnic parties also utilize their organizational networks in machine politics to ensure political success (Cox \& McCubbins, 1986; Dixit \& Londregan, 1995).

In all of these urban clientelistic practices, we observe coercive motives, instead of affective ones (as we observe in rural clientelism). In urban settings, repeated game structure of elections offers politicians coercive power in cases of defection, providing goods contingent on support (Stokes, 2005). In this regard, incumbents can establish credible threats against clients who renege on their commitments (Medina \& Stokes, 2007). However, secret ballots mostly prevent politicians from controlling the final choices of their clients. Thus, they can be claimed to buy 'turn-out', not the votes (hence the term, 'turn-out buying') (Nichter, 2008). Yet, political machines do their best to monitor their constituents, as seen in the case of Argentina where political parties use various mechanisms (such as ballot distribution, transportation of voters to the electoral offices etc.) to monitor the actions of their constituents quite effectively, if not perfectly (Manzetti \& Wilson, 2007; Stokes, 2005). Table 1 summarizes the differences between rural vs. urban modes of clientelism.

It would be inaccurate to assume that the aforementioned political notions of rural vs. urban modes of clientelism are strictly separate and totally unrelated to each other. Surely, increased institutionalization of party organization in many countries enables political parties to reach out citizens even in the most rural areas. Or, urban modes of clientelism in some shanty towns bear resemblances to certain notions of rural clientelism (such as 
Table 1. Differences between rural vs. urban modes of clientelism.

\begin{tabular}{|c|c|}
\hline$\underline{\text { Rural clientelism }}$ & Urban clientelism \\
\hline Normative bonds of deference and loyalty & $\begin{array}{l}\text { Competition between different providers of selective and } \\
\text { particularistic incentives }\end{array}$ \\
\hline Weberian traditional authority & Downsian motivations for political power \\
\hline $\begin{array}{l}\text { Affective ties between patrons and clients (ritual gift } \\
\text { exchanges; moral obligation) }\end{array}$ & $\begin{array}{l}\text { Political machines (more material inducements such as } \\
\text { jobs) }\end{array}$ \\
\hline Intrinsic reciprocity & Instrumental reciprocity \\
\hline Underdeveloped and/or secluded regions & Usually in urban periphery (shanty towns) \\
\hline
\end{tabular}

affective ties between patrons and clients) due to geographical seclusion in some metropolitan cities. In fact, the rural-urban divide in clientelism should be seen in a continuum, rather than two separate pockets of political vacuum. Yet, understanding the division and the underlying reasons behind rural and urban forms of clientelism can still be fruitful to comprehend the nature of political contestation in many countries, both at the local and national level. As we will see in the next section, certain regions in many countries (exemplified with Andalucía in Spain and Southeastern Anatolia in Turkey) can be more prone to rural modes of clientelism due to geographical seclusion, economic underdevelopment, and weaker political institutionalization. On the other hand, higher urbanization, industrialization, and economic affluence can trigger news forms of clientelism. It would be misleading to assume that same forms of patronage systems apply to all regions of a state. To this end, in-depth historical and sociopolitical analysis of different regions within states can offer us a more thorough picture about clientelism in general, which would then be helpful to grasp the political systems of countries as a whole. This research intends to offer such an analysis about the patron-client relationships in three South European countries, namely Greece, Spain, and Turkey.

\section{Case studies: Greece, Spain, and Turkey}

This study focuses on the patron-client relationships in Greece, Spain, and Turkey. The selection of these cases enables an intriguing and illuminating comparison of patronage systems in different political and socioeconomic contexts. A comparative study that focuses on Greece, Spain, and Turkey also sheds lights about clientelism in Southern Europe.

It would be appropriate to start with a brief discussion of sociopolitical changes in these three countries over time. As Table 2 shows, all of the three cases have urbanized considerably since the 1960s, particularly Greece and Spain. Yet, approximately $20-30 \%$ of the overall population of these three countries still live in rural areas. Furthermore, as the article will discuss in greater detail, rural modes of clientelism are more prevalent in

Table 2. Rural vs. urban populations in Greece, Spain, and Turkey since 1960.

\begin{tabular}{lllllllllllll}
\hline & \multicolumn{2}{c}{1960} & \multicolumn{2}{c}{1970} & \multicolumn{2}{c}{1980} & \multicolumn{2}{c}{1990} & \multicolumn{2}{c}{2000} & \multicolumn{2}{c}{2010} \\
\hline Greece & 44.06 & 55.94 & 35.78 & 64.22 & 30.66 & 69.34 & 28.53 & 71.47 & 27.28 & 72.72 & 23.71 & 76.29 \\
Spain & 43.43 & 56.57 & 33.96 & 66.04 & 27.21 & 72.79 & 24.65 & 75.35 & 23.74 & 76.26 & 21.56 & 78.44 \\
Turkey & 68.49 & 31.52 & 61.77 & 38.23 & 56.22 & 43.78 & 40.80 & 59.20 & 35.26 & 64.74 & 29.29 & 70.72 \\
\hline
\end{tabular}

Note: The former figures (shown in grey) for each time period refer to rural population for respective countries, whereas the latter ones (shown in white) are percentages of urban population. Source: World Bank Database, http://data.worldbank.org/. 
certain regions in these countries (Andalucía and Galicia in Spain and Eastern and Southeastern Anatolia in Turkey) due to geographical seclusion and historical antecedents. Hence, a clear distinction between rural vs. urban modes of clientelism in these three countries would help us better understand both the local- and national-level politics in these states.

There are various reasons to study these three countries in a comparative setting. First, these countries have shared many common features in their political history such as authoritarian regimes, coups, pronunciamientos, and many other undemocratic, quasidemocratic, or anti-democratic practices (Malefakis, 1995; McLaren, 2010), as well as the 'third-wave' of democratic transition (Huntington, 1996). Of course, there are differences among these countries too. For instance, Greece and Spain can be considered as consolidated democracies (Gunther, Diamandouros, \& Pühle, 1995) whereas Turkey has still some areas that limit its prospects for consolidation such as the ongoing (though weakening) legacies of the 1980 military coup (Özbudun, 1996) or the growing authoritarian tone of the ruling Justice and Development Party (AKP) (Özbudun, 2014). Yet, these differences do not hold us from offering a comparative perspective. In fact, some divergent paths these countries follow allow us to single out the forces behind the life cycle of their patron-client relationships. Second, Greece, Spain, and Turkey are Southern European and Northern Mediterranean countries, all of which are in the middle of a region that has brought about one of the most intriguing cases on clientelism. This gives the opportunity to utilize a considerable body of literature on these countries. Third, and linked to the first two points, two of these nations, that is, the Greeks and the Turks shared long periods of common history under the Ottoman rule (Clogg, 2010). Although the former was among the ruled and the latter was the ruler nation in general, we will see that centuries of the Ottoman reign led to many commonalities among these two nations on many aspects, including clientelism.

Patron-client relationships have existed in many countries, even in the most developed ones. But the phenomenon seems to have been more widespread and entrenched in the Southern European countries. In fact, according to some researchers, it did not diminish with time, but either retained or increased its strength during the twentieth century in these countries (Diamandouros, Gunther, Sotiropoulos, \& Malefakis, 2006, p. 17). As we will see in the succeeding portions of this research, patronage networks have existed in all of the three countries despite some changes through time.

\subsection{Greece: from Kodjabashis/Tzakia to Kommatarkhis}

To be able to understand the history of patron-client relationships in Greece, we should go back to the times of the Ottoman Empire. Ottomans ruled their subjects through the millet system, which was based on religious confession, rather than ethnic origin. The Ottomans called the Orthodox millet, which was the second largest after the Muslim millet, as the millet-i Rum or the 'Greek' millet. 'This was something of a misnomer for, besides the Greeks, it embraced all the Orthodox Christians of the Empire, whether they were Bulgarian, Romanian, Serb, Vlach, Albanian or Arab' (Clogg, 2010, p. 10). During the early phases of the nineteenth century, the Ottoman rule in the Balkans started to decay, which coincided with a rise of a small but influential group of Greeks into positions of power in the highest reaches of the Ottoman state. 
As Clogg (2010, pp. 20-21) suggests:

These were the Phanariots, who were drawn from a handful of families of Greek or Hellenized Romanian and Albanian origin. These Phanariots not only monopolized the office of principal interpreter to the Porte, but also acted as interpreters to the kapudan pasha, or admiral of the Ottoman fleet, and in this capacity came to act as the de facto governors of the islands of the Archipelago.

Besides the Phanariots who generally resided in Istanbul, Turkish overlords ruled Greece through local notables (i.e. kodjabashis), serving as intermediaries between the Ottoman state and Greek peasants.

Patronage had originally developed as a kind of defense mechanism against the harshness, and particularly the arbitrariness, of the Ottoman system of government. There was a need for patrons and protectors to mediate with the Ottoman authorities and to mitigate the capriciousness of the judicial system. (Clogg, 2010, p. 61)

One may expect to see the end of rural patron-client relationships after the demise of the Ottoman rule in Greece. Yet, it is not what the history brought about. After the Greek liberation in 1830, these relationships transformed but persisted where oligarchic families (tzakia) relied heavily on patronage and clientelism to control the voting processes (Kourvetaris \& Dobratz, 1987; Mouzelis, 1978). In fact, 'patronage proved wholly compatible with the formal institutions of parliamentary democracy. The local kommatarkhis or political boss simply took over the role of the Ottoman ağa (chief)' (Clogg, 2010, p. 61).

With rapid socioeconomic modernization and urbanization during the $1950 \mathrm{~s}$ and $1960 \mathrm{~s}$ and the establishment of mass party organizations in Greece, traditional clientelist control by local notables gave way to a new form of clientelism in which the party leadership played the definitive role in allocating state spoils. To be more specific, the two major political parties, Nea Demokratia and PASOK manipulated political business cycles by increasing social welfare payments in exchange for votes (Garcia \& Karakatsanis, 2006, pp. 102-122). This situation continued in the later phases of the twentieth century.

At this point, a Harvard economist-turned-politician, Andreas Papandreou requires specific attention. According to many researchers, Andreas Papandreou played a critical role on the continuity of patron-client relationships in Greece. According to Gunther and Diamandouros (2001, p. 397), the populism of Andreas Papandreou, who dominated party politics and government throughout the 1980s, coupled with the clientelism that permeated both PASOK and Nea Demokratia until the early 1990s, deterred both major parties from modernizing reforms. Writing an assessment about Andreas Papandreou, Clogg (1995) comes up with the question: 'Why did such a highly sophisticated and educated man behave like an old-fashioned kommatarkhis, or party boss, treating his party as his personal fiefdom?' In the same analysis, Clogg categorizes Papandreou as 'the last of the dinosaurs, as the Greeks call their geriatric ruling caste, rather than the first of the modernizers'.

Traditional patron-client relationships in Greece, with roots in agricultural society, have been transplanted into the urban centres and continue to enjoy a high level of popular acceptance even today (Garcia \& Karakatsanis, 2006, p. 89). This new form of patronclient relationships has permeated society at all levels and it continues to be a pronounced feature of society (Clogg, 2010, pp. 59-61). In general, we can sum up that rural patronclient relationships in Greece are transformed into new forms of clientelism. 
Socioeconomic modernization and growing rates of urbanization, coupled with the genesis of mass party organizations brought about the weakening of traditional patron-client relationships, which are replaced by pervasive urban patron-client relationships led by party bosses.

Recent studies on Greek politics and patron-client relationships centre on some critical issues. For instance, it is claimed that patronage politics affects the creation and development of civil society. Sotiropoulos (1996) argues that civil society and bureaucracy are still rather weak in contemporary Greece because they are both under the tutelage of very strong political parties, which utilize extensive patronage systems. In another important area of study, authors analyse the difficulties of state reform replete with patronage networks. As Tsoucalas (1978) maintains, some attempts have been made to reform the state and uproot the clientage relations from Greek politics (such as the ones by Charilaos Trikoupis) yet mostly other structural factors (e.g.: strong two-party system that benefited from clientelistic networks; see Lyrintzis, 1984) prevented the total achievement of the goals of such reforms. Specifically, Mavrogordatos (1997) claims that PASOK's accession to power in 1981 brought about a quantum leap in party patronage, and the transformation of traditional clientelism to extensive machine politics and 'bureaucratic clientelism' (through distribution of state resources and political favours to party supporters) in Greece (see also, Lyrintzis, 1987). Even after the weakening of the two-party system in recent years and the rise of other political parties such as SYRIZA (the Coalition of the Radical Left), Greek political system is still prone to clientelistic practices, specifically through machine politics.

\subsection{Spain: still the 'land' of caciques?}

The patron-client relationships in Spain can be traced back to the caciquismo system. Caciquismo is a form of patron-client relationship based upon reciprocal bonds between illiterate, poorly educated peasants, and local notables (Carr, 1966; Forner Muñoz, 1997). Cacique, the local elite, acted as a liaison between the villagers and the outer world through his literacy and personal networks.

There are some reasons why the caciquismo system was more rampant in certain regions of Spain. First, the geographic location of localities proves to be very important. Peasants in Northern Spain tended to own their own land with minimal class differences whereas the rural populations of Andalucía, Extremadura, and La Mancha were predominantly landless day labourers, employed in huge latifundia (Gunther, Montero, \& Botella, 2004 , p. 139). Thus, we can argue that land distribution in rural regions profoundly affected the social conditions in the society. Second, the size of the town or village is also an important variable (Gunther et al., 2004, p. 139). In this regard, Gilmore (1976, p. 99) points out the great differences between 'homogenous, unanimist, and independent peasant society' versus 'the more complex and heterogenous town society'. Finally, we can also talk about the technological advancements in agriculture that greatly influenced the lives of many in rural areas. Large-scale mechanization of agriculture (Harding, 1984) and the dissemination of agricultural subsidies through the EU (Gunther et al., 2004, p. 140) have played a role on the rising affluence of people in these areas.

Turning our attention to historical roots of rural patron-client relationships in Spain, we see that caciquismo was rampant during the Restoration Monarchy (1875-1923), 
specifically between 1870 s and 1890s (Malefakis, 1995, p. 54). Throughout this period, caciques manipulated the electoral processes that brought about a 'pseudo-competition between the two dominant parties' through 'peaceful turns' (turno pacifico) (Gunther et al., 2004, p. 140) and virtually eliminated the prospects of a fully democratic system. Historical records show us that the transition from Restoration Monarchy to the Second Republic (1931-1936) brought about an environment where economic and political coercive apparatuses of the caciques (coupled with the moral coercion by the Church) were hampered by freer and less corrupt elections and initiation of agrarian reforms (Araquistain, 1934, pp. 458-459; H.L., 1934, p. 5). Yet, the outbreak of the Civil War in 1936 and the successive authoritarian regime led by Francisco Franco nullified the gains of the Second Republic on this matter. The cultural and social structures of the caciquismo were restored after the Civil War. The victorious coalition used the caciquismo system to a large extent so as to suppress any remaining opposition, 'discipline' the masses, and restore the social order (Casanova, 2000, p. 530).

During the Franquist era, patron-client relationships were pervasive in rural areas, mainly in exchange for land speculation with the purpose of economic benefit rather than social welfare (Garcia \& Karakatsanis, 2006, p. 101). For this period, many researchers suggest that villagers in Spain exhibited a 'subject' orientation (Almond \& Verba, 1963; Lerner, 1958). The caciques controlled the political processes such as elections. In an astonishing interview, a villager told to Pitt-Rivers, 'when they tell me to vote, I ask, who for, and when they tell me who for, I vote. And if they don't ask me to vote, I stay at home and mind my own business' (Pitt-Rivers, 1954, p. 159).

Caciquismo appears to have declined in recent years in Spain. The sizeable bloc of poorly educated peasants, which is vital for this system has started to diminish in numbers, thanks to the economic and technological developments in rural areas and migration to the urban centres (Gunther et al., 2004, p. 141). This trend is more apparent in areas linked to metropolitan centres by adequate transportation networks (Tusell, 1978). Yet, caciquismo can still be seen as a theme of the day in economically underdeveloped areas that are physically isolated from the central bodies of the state. One stark example for this is the interior portions of Galicia, where the residents of the region are scattered across a mountainous topography, secluded from the political and administrative centres of the Spanish state (Roskin, 1979, p. 633). In rural areas of Galicia, caciquismo has survived into the current democratic era. The local notables in Galicia still function as 'the vehicle by which the citizen can resolve his problems' (Gunther et al., 2004, p. 25). Same kind of examples could also be seen in rural parts of Castile-Leon and Andalucía (Gunther et al., 2004, p. 141). Of course, it would be incorrect to claim that caciquismo is only confined to these areas. In fact, some researchers claim a new form of caciquismo, that is, caciquismo de partido (party caciquismo), which refers to close-knit ties of local party organizations and the implementation of public policy at the local level, exemplified by the distribution of unemployment compensation and agricultural subsidies is more prevalent nowadays (Cazorla, 1996). If this statement is correct, we can assert that caciquismo in rural areas has generally evolved into new forms of patronage.

Overall, we observe a transformation of patron-client relationships in Spain from rural areas to urban settings. The growing urbanization rates in Spain have altered the latifundist zones in the country and brought about massive migrations to the industrial cities such as Catalonia, Basque Country, and Madrid (Gunther et al., 2004, pp. 68-74). In this process, we 
also see a transformation of caciques into other positions in urban life, such as 'jobbers'. According to a relatively recent study, these jobbers supply factories and workshops with low-skill workers through a wide network of neighbourhood and kin ties (Narotzky, 2000, p. 6).

By and large, the rural patron-client relationships in Spain, crystallized by the caciquismo system, have started to lose its momentum. However, we observe a substitute for this system nowadays, namely caciquismo de partido in the countryside. Besides, urbanization and socioeconomic development altered the patron-client relationships and skewed the balance to more urban instances of patronage, as exemplified by the 'jobbers' in contemporary Spain.

\subsection{Turkey: the continuation of rural patronage and the birth of urban patronage}

To understand the patron-client relationships in Turkey, we should go back to the emergence of Turkish political parties during the reign of Young Turk movement (1908-1918). From this period on, most Turkish political parties have been 'internally created' within the circle of the governing elites. In local politics, this situation is reflected with the dominance of the leadership positions by the members of notable families (especially at the sub-province level) (Sayarı, 1976, pp. 187-196).

Besides the creation of political parties, another issue is worth mentioning, which is the schism between centre and periphery in Turkey. The divide between the 'centre' and the 'periphery' in Turkey has its roots in the Ottoman era. The Ottoman 'centre', which consisted of the intellectuals, the upper bureaucracy, and the military first emulated the Persian urban culture (e.g. elements of bureaucracy, language etc.) and then adopted a Western life style (Mardin, 1973). Western culture, which is also espoused by the elites of the Turkish Republic left the culture of the local notables and the peasants largely untouched. In this centre-periphery cleavage, orthodox Islam found itself on the side of the periphery against an increasingly secularized 'centre' (Mardin, 1973, pp. 178-179), both during the demise of the Ottoman rule and throughout the establishment of the new Turkish state, which effectively abolished the institutions of sultanate and caliphate and created the secular republican rule led by Mustafa Kemal Atatürk. One-party regime by the Republican People's Party (CHP in Turkish) continued until 1945 when Ismet Inönü, head of the ruling CHP allowed the formation of opposition parties (Rustow, 1966). This gave rise to the Democratic Party (DP in short), which was founded in 1946. The local support base of the DP was comprised of landowners, small merchants, religious leaders, and many local notables who opposed the secularist policies of the CHP (Leder, 1979, p. 84). This constituency paved the way for the success of the DP in Turkey's first free multi-party elections in 1950. Contra to the CHP's secular policies, the DP championed the cultural identity of 'periphery' and opposed to the bureaucratic oppression of the 'centre'. To illustrate, the first electoral motto of the DP in 1946 was 'Enough, now the people have their say!' ['Artık yeter, söz milletin!'] (Karpat, 1959, p. 161). After the success of the DP in 1950, the CHP followed the suit and established branches in villages and small towns (Leder, 1979, p. 86). After this date, cultivation of peasant support became an instrumental element for electoral success in Turkey. Compared to the politics in urban centres that have been pursued via various media such as newspapers, radio, 
and television, the politics in rural portions of the country have been dominated by personalistic ties (Leder, 1979, p. 87). Throughout the 1950s and 1960s, membership to party branches were predominantly tied to kinship groups where very few villagers were aware of the parties' programmes and goals (Szyliowicz, 1966). Lerner's (1958) seminal piece on patron-client relationships focuses on this issue. In this study, Lerner (1958) talks about the pivotal role that the local chief (muhtar) plays in the rural Balgat region in central Anatolia. Before this region was fully integrated into the core of capital city, Ankara, the muhtar acted almost as the sole bridge between the villagers and the world beyond the village, through possessing material resources (such as radio as the ultimate communication device of those times), literacy, and personal ties to the city. In exchange for the provision of various services to their clients, local notables (such as the chief in the case of Lerner's Balgat) created affective bonds with the local people (Legg, 1975) and exercised governmental authority.

This is not to say that the rural population was deaf to the variations among political parties. As Leder (1979, p. 91) argues:

While many villagers and small townsmen appear unconcerned with (and often unaware of) ideological differences between political parties and can, therefore, arbitrarily support one party or another, in some instances, the very nature of one or both of the conflicting solidary groups [such as different religious sects such as Sunni Islam versus Alawite Islam] may dictate party affiliation.

Familial ties have also played an important role in rural politics. Specifically, aşirets [tribes] have been highly influential in the Eastern and Southeastern Anatolia. They have played a significant role in the communal life in rural areas and also in the Turkish political arena for long periods of time. These familial ties are often tied to large land ownership, coined as ağalık in these regions. Ağa in a village holds vast amounts of land, which is reminiscent of latifundia land structure that existed in the southern parts of Italy, Spain, and Portugal ${ }^{2}$ (Dubetsky, 1976). These local elites have either themselves run in the elections to be mayors, parliamentarians etc. or have sponsored candidates that have close ties to them (Magnarella \& Türkdoğan, 1973; Sertel, 1971). Peasants in rural areas have usually acquiesced to the demands of these landlords and embraced the political stance of tribes (Rodrik, 1982). Combined with the large turn-out rates of rural areas during the elections (Leder, 1979), getting the backing of these landlords and tribes have been pivotal for political parties.

It is noteworthy here to state that there are some cleavages that are highly prominent in rural Turkey, which are also applicable to the case of tribes. In this regard, the major cleavages are religion and nationalism. As for religious cleavages, the main one is between the Sunni and Alawite sects of Islam. The dominant sect in these rural areas is the Sunni branch of Islam (both among the Turks and the Kurds) whereas the Alawite sect spread more particularly among the impoverished nomadic and semi-nomadic Kurdish and Turcoman tribes (Erman \& Göker, 2000, p. 110). In general, religion has acted as an important part of the identities of rural populations (Atacan, 2001) and has been a salient cleavage among tribes of different sects (Cizre-Sakallıoğlu, 1996, p. 233; Erman \& Göker, 2000, p. 111).

The second cleavage in rural Turkey lies in the nationalistic lines between Turkish and Kurdish identities. ${ }^{3}$ As a stark example, Bruinessen (1997) points out that contrary to the 
majority of Turkish Alawites, Kurdish Alawites were never at peace with the republican regime. This illustrates that when religious cleavages are controlled (both groups are Alawites in this example), national identities can still be salient among different tribes. Of course, one should note that the hotly debated 'Kurdish problem' and the military confrontation (though weakening in recent years) between the PKK (Kurdistan Workers' Party) and the Turkish military forces also deepen the national cleavages (Erman \& Göker, 2000, p. 100). All in all, local notables and large familial ties embodied in tribes have exploited both the religious and national cleavages (where possible) and tried to sustain their grip on local people through their economic and political ties. Wealth and a large network of acquaintances have been pivotal elements for these local notables to play a central role in politics and climb the echelons of political life -first in local organizations and then possibly and most probably in the Parliament (Heper \& Keyman, 1998, p. 263).

Although some claim that today tribes and tribal leaders cannot be as sure as they were in the past regarding the loyalty of the peasants (on political support they need to maintain their stronghold), we cannot prove this with solid facts. It is true that growing economic affluence, modernization, urbanization, outmigration, and technological advancements have played a role on the diminishing power of these rural settings (llcan, 1994). Yet, no political party in Turkey has ever dared to end this structure with bold, decisive, and long-term policies. Instead, when possible, they have exploited their ties with local strong men to perpetuate and possibly expand their political base. To be more specific, with the transition to multi-party democracy in 1945, Turkish political parties pursued the strategy of political patronage to cope with the socioeconomic problems and gather more votes. With the exception of the 1961-1965 and 1983-1987 periods, ${ }^{4}$ Dubetsky (1976) almost no effort has been made to develop coherent socioeconomic policies. Instead, politicians utilized their extensive local patronage networks to obtain votes (Heper \& Keyman, 1998, pp. 259-261). Additionally, the relative absence of a 'civil society' in Turkey's political structure (Karabelias, 1999) and the suspicion of the 'centre' elites towards intermediary groups and institutions (Akarlı \& Ben-Dor, 1975) permitted the political exploitation of the masses by local notables and religious leaders through the extensive use of patron-client relationships.

As Turkey has failed to institutionalize its political regime and consolidate its democracy, rural patron-client relationships have continued to be a major ingredient of the socioeconomic and political life in the countryside. Specifically, landlords and tribes in Eastern and Southeastern Turkey have acted as the local patrons of these areas and exploited the peasants through their economic and political resources. Political parties, with very few exceptions, have utilized their ties with local strongmen to continue, and if possible, broaden their political clout. Rural patron-client relationships in Turkey are far from becoming extinct and play a central role in politics. In a recent study, Özbudun (2005) talks about the pervasiveness of rural clientelism, which is not be limited to certain geographic regions. The author asserts that patronage can prove strong even in the rural areas of relatively affluent western and southwestern regions (though under different contexts).

Along with the rural patronage networks, contemporary studies on Turkey show bourgeoning forms of urban clientelism. In a study that supports this phenomenon, Güneş-Ayata (1994) claims that patronage and clientage have proven remarkably portable and adaptable during the past century as Turkey has transitioned from a new, mainly rural 
state in which patronage and clientage existed most classically in the landlord-peasant relationship, to a modernizing, urbanizing state in which machine politics is more prevalent. In a very to-the-point analysis, Hale (1999) maintains that there is voter alienation from the political system in Turkey, where party identification is weak and electoral volatility is high. This makes political parties resort to further patronage practices to ensure their political support in this volatile environment. Overall, this creates a self-reinforcing mechanism for clientelism.

\section{Current state of clientelism in Greece, Spain, and Turkey}

A comparative research that studies patron-client relationships in Greece, Spain, and Turkey highlights interesting commonalities as well as differences among these countries. As this research suggests, tzakia/kodjabashis in Greece, cacique/caciquismo in Spain, and ağalık/aşirets in Turkey refer to the rural versions of patronage whereas kommatarkhis in Greece and caciquismo de partido in Spain are relevant for clientelistic practices in urban areas. Due to its socioeconomic development, urbanization, and industrialization, as well as its geography, Greece usually has urban modes of clientelism. Spain also has similar features about the current state of clientelism yet certain regions of the country, especially Galicia, as well as Castile-Leon and Andalucía have still rural modes of patronage systems due to their geographical conditions. Likewise, mountainous and secluded regions in Turkey, especially Eastern and Southeastern Anatolia are still under heavy influence of rural clientelism whereas urbanized and industrialized western portions of the country have evolved into political environments apt for machine politics.

Brief notes should be made regarding the current state of clientelism in each of the three cases at hand. Major political parties and party systems within which they operate, as well as the contemporary socioeconomic conditions are essential to understand how patron-client relationships work as of today in these three states. To start with, the 2008 global crisis shook the Greek party system immensely. Dynastic politics, characterized by family ties in the Greek Parliament and linked to the persistence of clientelism in Greece, started to wither away with the 2012 election (Patrikios \& Chatzikonstantinou, 2015). The political scene dominated by two parties (PASOK and Nea Demokratia) has been revolutionized by the rise of anti-system parties, especially SYRIZA, which has recently come to the government in the 2015 election. Greece, as a country adversely and significantly affected by the global financial crisis, has been provided with some restructuring demands by the EU, ECB, and IMF. These demands have been centred on cutting back on the bloated public bureaucracy. Yet, the political parties have been reluctant to follow the advice of these international organizations, which would sacrifice the patronage networks upon which the Greek parties have depended over the past several decades. Endemic prevalence of clientelistic networks, which has created the background for corruption and economic malaise is hard to eradicate from the Greek politics (Christopoulos, 1998). SYRIZA, as a radical left-wing party with its populist discourse, promises to replace the corrupt political system in Greece replete with clientelism with one that cares the interests of 'the people' (signified by the term ' $\lambda a c^{\prime} \varsigma^{\prime}$ ), especially the downtrodden segments of the society (Stavrakakis \& Katsambekis, 2014). In the context of continued economic hardships and the concomitant decline in the support for parliamentary democracy 
(Teixeira, Tsatsanis, \& Belchior, 2014), SYRIZA has a tough row to hoe to honour its political and economic promises and eradicate clientelistic practices in the Greek politics.

Similar to the Greek case, the Spanish economy has also been struck hard by the global financial crisis. The political scene has long been dominated by two parties, center-right People's Party (PP) and center-left Spanish Socialist Workers' Party (PSOE) (Bosco \& Morlino, 2006). Clientelism, be it in rural areas or urban centres, persists in democratic era (Fernandes, 2014). Especially, urban modes of clientelism, particularly in the form of 'bureaucratic clientelism' (Lyrintzis, 1987), through distribution of state resources and political favours to party devotees, prevails in the Spanish politics (Hopkin, 2001; Pujas \& Rhodes, 1999). Alienated by clientelistic and corrupt networks of system parties and exhausted by economic hardships, many Spaniards have started to challenge the status quo in recent years. In the aftermath of the 2011-2012 Spanish protests against inequality and corruption, a left-wing political party, Podemos ('We Can') was founded. Similar to the case of SYRIZA, Podemos stands to revolutionize the extant political system in Spain. In the run up to the Spanish general election of December 2015, Podemos is currently the third party in the polls, closely following its major contenders, the PP and PSOE. Making crucial gains in the most recent local and regional elections in May 2015 (such as holding power in Barcelona), Podemos challenges the traditional political parties and party system in Spain. Much like the SYRIZA case in Greece, however, it is still a long way to go for political parties such as Podemos to fully replace the clientelistic, corrupt networks of political power in Spain.

In the Turkish case, the ruling AKP has dominated the political scene in the country since the early 2000s. AKP's current rule can be best characterized by a 'drift towards an excessively majoritarian conception of democracy, or even an electoral authoritarianism of a more markedly Islamic character' (Özbudun, 2014, p. 1). Within this political context, the distribution of goods, services, and jobs in exchange for votes through clientelism and patronage plays an important role in shaping the voters' preferences in Turkey (Sayarı, 2014, p. 655). Politicians favour and look after the interests of their supporters at the expense of violating the neutrality principle (Adaman, 2011, p. 314). In a recent illuminating study, Çarkoğlu and Aytaç (2015) show that clientelism is rampant in the Turkish society, in which $35 \%$ of the whole population is targeted for clientelistic practices (Çarkoğlu \& Aytaç, 2015, p. 2). The scholars underline that strong partisans of the ruling AKP, less-educated individuals, and urban residents are the biggest segments of the society who are targeted for vote-buying (Çarkoğlu \& Aytaç, 2015, pp. 2-3; p. 11). All in all, the current competitive authoritarian party system dominated by the ruling AKP reinforces the patron-client relationships in Turkey (especially in urban settings), instead of coping with them and replacing them with programmatic appeals.

To sum up, in rural modes of clientelism, normative bonds of deference and loyalty with a Weberian notion of 'traditional authority' and affective ties between political patrons and clients are more observable whereas urban modes of clientelism evidently bring about Downsian competition between political machines with more coercive motives. This does not mean that these notions of clientelism are mutually exclusive. This rural-urban divide should be seen in a continuum. Surely, party politicking is part of the political picture in villages and shanty towns in urban periphery bear notions of 'rural' patronage systems due to their geographical seclusion. However, studying clientelism with more contextualized analyses that take into account differences between socioeconomic and 
geographical antecedents of rural vs. urban clientelism and their divergent political reflections would help us further the extant body of literature on this subject. To this end, this study has attempted to provide the evolution of patronage systems in Greece, Spain, and Turkey through the prism of this rural-urban divide. In general, it can be argued that urban modes of clientelism (especially in the shape of 'bureaucratic clientelism') dominates the political scene as of today, whereas rural clientelism still prevails in certain geographic regions of these states. Hopefully, this study will help us promote our understanding about the polities in these states and contribute to the literature on clientelism.

\section{Notes}

1. According to Finan and Schechter (2012), intrinsic reciprocity is a person's willingness to sacrifice his own material well-being in order to increase the payoffs of someone who has been kind to him or to decrease the payoffs of someone who has been unkind to him. This is contrasted with instrumental reciprocity, which is motivated by forward-looking self-interest.

2. The word ağa is frequently used to refer to the merchant in town as well as to the rural landlord. It is also used in some parts of Anatolia as a form of address by a son for his father or elder brother (Dubetsky, 1976, 441).

3. The other significant identities that play a role in rural Turkey (where aşirets dominate) are the Arab and Zaza identities (Erman \& Göker, 2000, 111).

4. 1961-1965 period was governed by the center-left Republican People's Party. At this period, planning instead of patronage, industrial growth instead of populism, and an urban, polished universalism instead of rural parochialism were emphasized (Sunar, 1994, 101). On the other hand, 19831987 period was governed by the center-right Motherland Party (led by Turgut Özal). In this early Özal period, economic decisions tended to be responsive to market signals and they were not dictated by clientelist demands (Heper \& Keyman, 1998, 266).

\section{Acknowledgements}

The author would like to thank Richard Gunther and Meral Ugur Cinar for their insightful and expert comments on the earlier drafts of the article. I also would like to thank the participants of the International Political Economy Society of Turkey Conference at Koc University, especially Isik Ozel and Caner Bakir for helping me further develop and clarify my theoretical framework in the article. As always, all responsibility for errors lies with the author.

\section{Disclosure statement}

No potential conflict of interest was reported by the author.

\section{Notes on contributors}

Dr. Kursat Cinar earned his PhD in Political Science from the Ohio State University. His research interests center on party politics, democratization, patron-client relationships, and development. He has published in Political Studies, Democratization, Mediterranean Politics, Journal of Balkan and Near Eastern Studies, and Turkish Studies. He is the recipient of the 2013 Sabanci International Research Award and a Fulbright Alumnus. He is currently a Lecturer at Bilkent University. 


\section{References}

Adaman, F. (2011). Is corruption a drawback to Turkey's accession to the European Union? South European Society and Politics, 16(2), 309-321.

Akarlı, E. D., \& Ben-Dor, G. (1975). Political participation in turkey: Historical background and present problems. Istanbul: Boğaziçi University Press.

Alamdari, K. (2005). The power structure of the Islamic republic of Iran: Transition from populism to clientelism, and militarization of the government. Third World Quarterly, 26(8), 1285-1301.

Almond, G., \& Verba, S. (1963). The civic culture. Princeton, NJ: Princeton University Press.

Anderson, C. W. (1967). Politics and economic change in Latin America. Princeton, NJ: Van Nostrand.

Ansell, A., \& Mitchell, K. (2011). Models of clientelism and policy change: The case of conditional cash transfer programmes in Mexico and Brazil. Bulletin of Latin American Research, 30(3), 298-312.

Araquistáin, L. (1934). The struggle in Spain. Foreign Affairs, 12(3), 458-471.

Atacan, F. (2001). A Kurdish Islamist group in modern Turkey: Shifting identities. Middle Eastern Studies, 37(3), 111-144.

Auyero, J. (1999). From the client's point of view: How poor people perceive and evaluate political clientelism. Theory and Society, 28, 297-334.

Bosco, A., \& Morlino, L. (2006). What changes in South European Parties? A comparative introduction. South European Society and Politics, 11(3-4), 331-358.

Bruinessen, M. (1997). 'Aslini inkar eden haramzadedir!': The debate on the ethnic identity of the Kurdish Alevis. In K. Kehl-Bodrogi, B. Kellner-Heinkele, \& A. Otter-Beaujean (Eds.), Syncretistic religious communities in the near East (pp. 1-23). Leiden: Brill

Burgwal, G. (1995). Struggle of the Poor: Neighborhood organization and clientelist practice in a quito squatter settlement. Amsterdam: CEDLA.

Çarkoğlu, A., \& Aytaç, E. (2015, May). Who gets targeted for vote-buying? Evidence from an augmented list experiment in Turkey. European Political Science Review, 7(4), 547-566.

Carr, R. (1966). Spain: 1808-1939. London: Oxford University Press.

Casanova, J. (2000). Civil wars, revolutions and counterrevolutions in Finland, Spain, and Greece (1918-1949): A comparative analysis. International Journal of Politics, Culture, and Society, 13(3), 515-537.

Cazorla-Perez, J. (1996). El clientelismo de partido en la España de hoy: una disfuncion en la democracia. In Antonio Robles (Ed.), Politica en penumbra: patronazgo y clientelismo politicos en la España contemporanea. Madrid: Siglo XXI.

Chaves, M. S. (2002). Organizational empowerment versus clientelism. Latin American Perspectives, 29 (5), 7-19.

Christopoulos, D. (1998). Clientelistic networks and local corruption: Evidence from Western Crete. South European Society and Politics, 3(1), 1-22.

Cizre-Sakallığlu, Ü. (1996). Parameters and strategies of Islam-State interaction in Republican Turkey. International Journal of Middle East Studies, 28(2), 231-251.

Clogg, R. (1995). From academy to acropolis. Times Higher Education. Published in December 22nd 1995. Retrieved from http://www.timeshighereducation.co.uk/story.asp?storyCode=96331\&sectioncode $=26$

Clogg, R. (2010). A concise history of Greece. Cambridge: Cambridge University Press.

Coppedge, M. (2001). Latin American parties: Political Darwinism in the lost decade. In Larry Diamond \& Richard Gunther, (Eds.), Political parties and democracy (pp. 173-206). Baltimore, MA: JHU Press.

Corstange, D. (in press). The price of a vote in the Middle East. Cambridge: Cambridge University Press.

Cox, G., \& McCubbins, M. D. (1986). Electoral politics as a redistributive game. The Journal of Politics, 48 (2), 370-389.

Diamandouros, P. N., Gunther, R., Sotiropoulos, D. A., \& Malefakis, E. E. (2006). Introduction: Democracy and the state in the New Southern Europe. In Richard Gunther, P. Nikiforos Diamandouros, \& Dimitri A. Sotiropoulos (Eds.), Democracy and the state in the New Southern Europe (pp. 1-41). Oxford: Oxford University Press.

Diaz-Cayeros, A., Magaloni, B., \& Weingast, B. R. (2002, August 29-September 1). The erosion of oneparty rule: Clientelism, portfolio diversification and electoral strategy. Paper prepared for delivery at the 2002 annual meeting of the American Political Science Association, Boston. 
Dixit, A., \& Londregan, J. (1995). Redistributive politics and economic efficiency. The American Political Science Review, 89, 856-866.

Dubetsky, A. (1976). Kinship, primordial ties, and factory organization in Turkey: An anthropological view. International Journal of Middle East Studies, 7(3), 433-451.

Erman, T., \& Göker, E. (2000). Alevi politics in contemporary Turkey. Middle Eastern Studies, 36(4), 99-118.

Fernandes, T. (2014). Rethinking pathways to democracy: Civil society in Portugal and Spain, 1960s2000s. Democratization 22(6), 1074-1104.

Finan, F., \& Schechter, L. (2012). Vote-Buying and Reciprocity. Econometrica, 80, 863-881.

Forner-Muñoz, S. (1997). Democracia, elecciones y modernización en Europa. Madrid: siglos XIX.

Garcia, M., \& Karakatsanis, N. (2006). Social policy, democracy, and citizenship in Southern Europe. In Richard Gunther, P. Nikiforos Diamandouros, \& Dimitri A. Sotiropoulos (Eds.), Democracy and the state in the New Southern Europe (pp. 87-137). Oxford: Oxford University Press.

Garcia-Guadilla, M. P. (2002). Democracy, decentralization, and clientelism: New relationships and old practices. Latin American Perspectives, 126(29), 90-109.

Gilmore, D. D. (1976). Class, culture, and community size in Spain: The relevance of models. Anthropological Quarterly, 49, 89-106.

Grzymala-Busse, A. (2008). Beyond clientelism: Incumbent state capture and state formation. Comparative Political Studies, 41(4/5), 638-673.

Güneş-Ayata, A. (1994). Roots and trends of clientelism in Turkey. In Luis Roniger \& Ayse Günes-Ayata (Eds.), Democracy, clientelism, and civil society (pp. 49-63). Boulder, CO: Lynne Rienner.

Gunther, R., \& Diamandouros, P. N. (2001). Conclusion. In P. Nikiforos Diamandouros \& Richard Gunther (Eds.), Parties, politics, and democracy in the New Southern Europe (pp. 388-398). Baltimore, MD: Johns Hopkins University Press.

Gunther, R., Diamandouros, N., \& Pühle, H. (Eds.). (1995). The Politics of democratic consolidation: Southern Europe in comparative perspective. Baltimore: The Johns Hopkins University Press.

Gunther, R., Montero, J. R., \& Botella, J. (2004). Democracy in modern Spain. New Haven, CT: Yale University Press.

Hale, W. (1999). Turkey's domestic political landscape: A glance at the past and the future. The International Spectator, 34(1), 27-45.

Harding, S. (1984). Remaking Ibieca: Rural life in Aragon under Franco. Chapel Hill: University of North Carolina Press.

Heper, M., \& Keyman, E. F. (1998). Double-Faced State: Political patronage and the consolidation of democracy in Turkey. Middle Eastern Studies, 34(4), 259-277.

Hicken, A. (2007). How effective are institutional reforms? In F. C. Schaffer (Ed.), Elections for sale: The causes and consequences of vote buying (pp. 45-160). Boulder, CO: Lynne Rienner Publishers.

Hopkin, J. 2001. A 'Southern Model' of electoral mobilization? Clientelism and electoral politics in Spain. West European Politics, 24(1), 115-136.

Huntington, S. P. (1996). Democracy's third wave. In Larry Diamond \& Marc Plattner (Eds.), The global resurgence of democracy (pp. 3-25). Baltimore, MD: Johns Hopkins University Press.

Ilcan, S. M. (1994). Peasant struggles and social change: Migration, households and gender in a rural Turkish society. International Migration Review, 28(3), 554-579.

Karabelias, G. (1999). The evolution of civil-military relations in post-war Turkey, 1980-1995. Middle Eastern Studies, 35(4), 130-151.

Karpat, K. (1959). Turkey's politics: The transition to a multi-party system. Princeton, NJ: Princeton University Press.

Kaufman, R. R. (1974). The patron-client concept and macro-politics: Prospects and problems. Comparative Studies in Society and History, 16(3), 284-308.

Keating, M. (1999). The politics of modern Europe: The state and political authority in the major democracies (2nd ed.). Cheltenham: Edward Elgar.

Keiser, R. A. (2001). Political machine. In J. Krieger (Ed.), The Oxford companion to politics of the world (2nd ed. (pp. 666-667)). Oxford: Oxford University Press.

Kitschelt, H. (2000). Linkages between citizens and politicians in democratic polities. Comparative Political Studies, 33(6/7), 845-879. 
Kitschelt, H., \& Wilkinson, S. (2007). Patrons, clients, and policies: Patterns of democratic accountability and political competition. Cambridge: Cambridge University Press.

Kourvetaris, Y., \& Dobratz, B. (1987). A profile on modern Greece: In search of identity. Oxford: Clarendon Press.

H. L. (1934). A crisis in the history of Spain. Bulletin of International News, 11(8), 3-13.

Lande, C. H. (1973). Networks and groups in Southeast Asia: Some observations on the group theory of politics. The American Political Science Review, 67(1), 103-127.

Lauth, H. J. (2000). Informal institutions and democracy. Democratization, 7, 21-50.

Leder, A. (1979). Party competition in Rural Turkey: Agent of change or defender of traditional rule? Middle Eastern Studies, 15(1), 82-105.

Legg, K. (1975). Patron, clients, and politicians (Working Papers on Development, No. 3), Berkeley: Institute of International Studies, University of California.

Lémarchand, R., \& Legg, K. (1972). Political clientelism and development: A preliminary analysis. Comparative Politics, 4(2), 149-178.

Lerner, D. (1958). The passing of traditional society. New York, NY: Free Press.

Levitsky, S. R., \& Way, L. A. (2012, November). Beyond patronage: Violent struggle, ruling party cohesion, and authoritarian durability. Perspectives on Politics, 10, 869-889.

Lindberg, S. I., \& Morrison, M. K. C. (2008). Are African voters really ethnic or clientelistic? Survey evidence from Ghana. Political Science Quarterly, 123(1), 95-122.

Lyrintzis, C. (1984). Political parties in post-junta Greece: A case of 'bureaucratic clientelism'? West European Politics, 7(2), 99-118.

Lyrintzis, C. (1987). The power of populism: The Greek case. European Journal of Political Research, 15, 667-686.

Magaloni, B., Diaz-Cayeros, A., \& Estevez, F. (2007). Clientelism and portfolio diversification: A model of electoral investment with applications to Mexico. In Herbert Kitschelt \& Steven I. Wilkinson (Eds.), Patrons, clients, and policies: Patterns of democratic accountability and political competition (pp. 182-205). Cambridge: Cambridge University Press.

Magnarella, P. J., \& Türkdoğan, O. (1973). Descent, affinity, and ritual relations in Eastern Turkey. American Anthropologist, 75(5), 1626-1633.

Malefakis, E. (1995). Contours of Southern European history. In Richard Gunther, P. Nikiforos Diamandouros, \& Hans-Jürgen Puhle (Eds.), The politics of democratic consolidation: Southern Europe in comparative perspective (pp. 37-76). Baltimore, MD: Johns Hopkins University Press.

Manzetti, L., \& Wilson, C. J. (2007). Why do corrupt governments maintain public support?. Comparative Political Studies, 40(8), 949-970.

Mardin, Ş. (1973). Center-Periphery relations: A key to Turkish politics? Daedulus, 102(1), pp. 169-133.

Mavrogordatos, G. T. (1997). From traditional Clientelism to machine politics: The impact of PASOK populism in Greece. South European Society and Politics, 2(3), 1-26.

McLaren, L. M. (2010). Constructing democracy in Southern Europe: A comparative analysis of Italy, Spain, and Turkey. London: Routledge.

Medina, L. F., \& Stokes, S. (2007). Monopoly and monitoring: An approach to political clientelism. In Herbert Kitschelt \& Steven Wilkinson (Eds.), Patrons, clients, and policies: Patterns of democratic accountability and political competition (pp. 68-83). Cambridge: Cambridge University Press.

Mouzelis, N. (1978). Class and clientelistic politics: The case of Greece. The Sociological Review, 26(3), 471-497.

Narotzky, S. (2000). The cultural basis of a regional economy: The Vega Baja del Segura in Spain. Ethnology, 39(1), 1-14.

Nichter, S. (2008). Vote buying or turnout buying? Machine politics and the secret ballot. American Political Science Review, 102(1), 19-31.

Özbudun, E. (1996). Turkey: How far from consolidation? Journal of Democracy, 7(3), 123-138.

Özbudun, S. (2005). The reproduction of clientelism in regressing rural Turkey or "Why i became an 'erect ear'?". Dialectical Anthropology, 29, 241-272.

Özbudun, E. (2014). AKP at the crossroads: Erdoğan's majoritarian drift. South European Society and Politics, 19(2), 155-167. 
Patrikios, S., \& Chatzikonstantinou, M. (2015). Dynastic politics: Family ties in the Greek Parliament, 2000-2012. South European Society and Politics, 20(1), 93-111.

Pitt-Rivers, J. (1954). The people of the sierra. London: Weidenfeld and Nicolson.

Powell, J. D. (1970). Peasant society and clientelistic politics. The American Political Science Review, 64 (2), 411-425.

Pujas, V., \& Rhodes, M. (1999). Party finance and political scandal in Italy, Spain and France. West European Politics, 22(3), 41-63.

Rodrik, D. (1982). Rural transformation and peasant political orientations in Egypt and Turkey. Comparative Politics, 14(4), 417-442.

Roskin, M. (1979). Spain tries democracy again. Political Science Quarterly, 93(4), 629-646.

Rustow, D. A. (1966). The development of parties in Turkey. In Joseph La Palombara \& Myron Weiner (Eds.), Political parties and political development (pp. 107-133). Princeton, NJ: Princeton University Press.

Sayarı, S. (1976). Aspects of party organization in Turkey. Middle East Journal, 30(2), 187-199.

Sayarı, S. (2014). Interdisciplinary approaches to political clientelism and patronage in Turkey. Turkish Studies, 15(4), 655-670.

Scott, R. E. (1967). Political elites and political modernization. In Seymour Lipset \& Aldo Solari (Eds.), Elites in Latin America (pp. 117-145). New York, NY: Oxford University Press.

Scott, J. S. (1972). Patron-client politics and political change in Southeast Asia. The American Political Science Review, 66(1), 91-113.

Sotiropoulos, D. (1996). Populism and bureaucracy: The case of Greece under PASOK. Notre Dame, IN: University of Notre Dame Press.

Sertel, A. K. (1971). Ritual kinship in Eastern Turkey. Anthropological Quarterly, 44(1), 37-50.

Stavrakakis, Y., \& Katsambekis, G. (2014). Left-wing populism in the European periphery: The case of SYRIZA. Journal of Political Ideologies, 19(2), 119-142.

Stokes, S. C. (2005). Perverse accountability: A formal model of machine politics with evidence from Argentina. American Political Science Review, 99(3), 315-325.

Stokes, S. C., Dunning, T., Nazareno, M., \& Busco, V. (2013). Brokers, voters, and clientelism: The puzzle of distributive politics. Cambridge: Cambridge University Press.

Szyliowicz, J. S. (1966). Political change in rural Turkey: Erdemli. The Hague: Mouton and Co.

Teixeira, C. P., Tsatsanis, E., \& Belchior, A. M. (2014). Support for democracy in times of crisis: Diffuse and specific regime support in Portugal and Greece. South European Society and Politics, 19(4), 501-518.

Theobald, R. (1983). The decline of patron-client relations in developed societies. European Journal of Sociology, 24, 136-147.

Tsoucalas, C. (1978). On the problem of political Clientelism in Greece in the nineteenth century. Journal of the Hellenic Diaspora, 5, 5-19.

Tusell, J. (1978). El sistema caciquil andaluz comparado con el de otras regiones españolas (19031923). REIS, 2, 7-20.

Weber, M. (1957). Traditional authority. In M. Weber, A. Henderson, \& T. Parsons (Eds.), Theory of social and economic organization (pp. 341-358). Glencoe, IL: Free Press.

Wilson, J. Q. (1961). The economy of patronage. Journal of Political Economy, 69(4). 369-380. 